\title{
ONLINE RESERVATIONS AND HOTEL DISTRIBUTION CHANNELS IN EUROPEAN TOURISM: A CASE OF CROATIA
}

\author{
Dadić, I., Slivar, I., Floričić, T.
}

Iva Dadić / Juraj Dobrila University of Pula, Faculty of Economics and Tourism, Department of Tourism, Preradovićeva 1, HR- 52100 Pula, Croatia.Email: iva.dadic@unipu.hr

Iva Slivar / Juraj Dobrila University of Pula, Faculty of Economics and Tourism, Department of Tourism, Preradovićeva 1, HR- 52100 Pula, Croatia.Email: iva.slivar@unipu.hr

Tamara Floričić / Juraj Dobrila University of Pula, Faculty of Economics and Tourism, Department of Tourism, Preradovićeva 1, HR- 52100 Pula, Croatia.Email: tamara.floricic@unipu.hr

\begin{abstract}
Technologies transform the total marketing mix of hotel products in the dynamic tourism market, where the distribution is detected as a key factor of market placement and profitability. The main goal of this paper is to explore the distribution channels in the hospitality industry and to identify the most successful elements of online distribution for the purposes of realising future excellence in post-COVID-19 tourism. The online distribution elements that could enhance competitiveness and incentives for reservation were identified and ranked. This was realised by choosing the most representative sample and by researching it using a structured questionnaire, where the mix of competitiveness and marketing elements were evaluated. The research findings present the importance of online travel agents (OTA), tour operators, social networks and conferences (MICE segment). The potential of Global Distribution Systems (GDS) systems is detected and, although not fully valorised in practice, implicate future franchising and contracting with global hotel brands and consortia. The answer to the question: "Which tools and techniques of innovative online distribution should be used and what product elements enhance sales in the hotel industry of the future?" is explored by the scientific methodology, which supports the purpose and presents the main contribution of the paper.

Implications for Central European audience: The paper represents a considerable contribution in the perception of the distribution channels, affirmed for exchange in the Central European tourism market as an emissive market for the receptive offer of Croatian tourism. Considered in the context of the accessibility of Croatia as a car destination that realises both long-term and short-term "impulsive" bookings, promptness, propulsion and dynamism of online distribution channels used by the hotel offer have exceptional importance for income management and profitability. Correspondingly, a positive perception is being developed of the Central European market demand, as well as tourism awareness about closeness and market potentials, which represents a platform for the development of applicative strategies in communication and business. Recognising the effect on intensification of tourist exchange through the affirmation of innovations and technology contributes to the development of science and practice of the hospitality industry.
\end{abstract}

Keywords: online reservations; distribution channels; hotel industry; competitiveness 


\section{Introduction}

During the last decade, tourism demand trends have been changing much faster in relation to tourism supply trends. Tourists are those stakeholders who dictate the trends when it comes to tourism supply, and hoteliers, campsites, private accommodation facilities and hospitality facilities, on the other hand, are those who adapt to the imposed tourism supply trends. In the last thirty years or so, the number of days which tourists spend on holidays has reduced; more and more often they wish to experience something new and authentic and a holiday is no longer just "the sun and the sea". With the emergence of low-cost airlines, tourists increasingly decide to use planes as their means of transport, although cars continue to be the dominant means of transport.

The virtual tourism market has experienced substantial growth and has imposed as a "big player" in the tourism market. The emergence of online tourist agencies for accommodation bookings, such as Booking.com, Airbnb, Expedia and others, which operate in the same manner, have shaken the traditional methods of booking of all types of accommodation. At online tourist agencies, travellers can find reviews left by some of the previous guests who had stayed in a particular accommodation facility and, in this way, are able to get an idea about a specific accommodation facility, which is of big help to them when making a decision about choosing that very accommodation facility. On the other hand, traditional tourist agencies and, generally, all the other stakeholders in tourism supply have also had to adapt to new trends by means of investing considerable funds in technology, employee education/training and marketing, in order to compete with online tourist agencies and to keep up with the modern trend of short-term bookings (Kot et al., 2019). Comprehending the facts and thriving for deeper understanding, the main goal of the paper is pointed out: an exploration of the distribution channels in the hospitality industry for the identification of the most successful elements of online distribution for the purposes of realising future excellence in post-COVID-19 tourism. This exploration is focused on answers to research question related to the identification of the most successful elements of online distribution channels impacting successful bookings and marketing results.

In this paper, the authors explore and illustrate the trends in hotel accommodation bookings in the years running up to the pre-COVID-19 tourism period and the situation in the Republic of Croatia's tourism market. The trends in the domestic market will then be compared with the trends in the European market. Briefly, they represent a platform for evaluation and development of post-COVID-19 tourism, on which imposed health and safety standards, social distancing and content reorganisation will have an impact. In the paper, a special accent is put on the trends in hotel accommodation bookings by sales channels (direct and indirect distribution channels) and the analysis of each hotel accommodation sales channel, comparing the data of some countries within the European Union, including also the Republic of Croatia, as a country which belongs to the Mid-European post-transition economic environment and which initiated its tourism development and hospitality business due to an expansion of interest by the Central European emissive markets. 
After the introduction follows the theory and literature review followed by methodology explanation in the second chapter, the central part of the paper structured as a research and discussion chapter encompass an analysis of the research results obtained by the survey carried out with four and five-star hotels in the Republic of Croatia concerning the trends in online hotel accommodation bookings. The obtained data are analysed and compared with already existing sublimated research and studies which are available on the Internet and which, in a fragmented manner, analyse the corresponding issues. To conduct the research, a questionnaire was created, which was distributed to all four and five-star hotels in the Republic of Croatia. Obtained feedback was compared with already existing available research, and new knowledge was acquired. The conclusion chapter resumes research results and presents paper contribution as well as less explored trends as a platform for future research.

\section{Contemporary trends in the hotel distribution in Europe - theoretical background}

In 2015, the European travel market increased by $5 \%$ in comparison with the previous year and equalled 264 billion euros. During the years 2016 and 2017, the growth was lower and equalled $3 \%$, and, in 2017, the travel market was valued at 280 billion euros, stressed Charuta et al. (2016). In 2019, the European travel market grew by $2 \%$ in relation to the year 2018, equalling 296 billion euros (Menze, 2019).

Although the prospects are generally positive, a few factors will obstruct and prevent tourism growth in the future. One of the most important factors which will impact tourism in Europe is the voting of Great Britain in June 2016 to leave the European Union (EU), popularly called Brexit, which has created great uncertainty and affected travel bookings in Europe, considered by Dutta et al. (2020). Also, other European countries, such as Italy, France and Spain, rely on Great Britain as a substantial emissive country and, with Brexit, also the travel of British tourists to foreign countries, a possibility of the introduction of visas, greater border control and similar, is called into question, elaborated Bramwell (2020).

In Turkey, North Africa and the Near East, terrorist activities continue, and travellers prefer to choose some other destinations instead of these, in which the safety situation is currently unstable. In Europe also, there were several terrorist attacks, namely in Brussels, Berlin and Nice, and the migrant crisis continues following the large migrant wave back in 2015 (Mawby et al., 2021; Tauringana et al., 2020). The emergence of the pandemic caused by COVID-19 has had a big impact on the reduction in tourist trends, which will cause long-term consequences for economies and tourism throughout the world. Sigala (2020) linked and opposed the character of tourism and the consequences of the pandemic, pointing out that this health crisis is not only different from others, but that will leave deep and far-reaching structural consequences for tourism and socio-economic activities and industry.

In relation to the entire travel market, online bookings have been progressing continually. The growth of online bookings in 2016 was 7\%, which represents three times higher growth in relation to the increase in total bookings in the tourism market, which, in 2016 , equalled $2 \%$. The predictions before the emergence of the pandemic caused by the COVID-19 virus were that, in the year 2020, the total tourism market would be worth 310 billion euros and that the online market would occupy more than half of the total market and be worth almost 180 billion euros (Juman et al., 2016). 
In 2016, Europe reached a turning point, and half of all gross bookings were made using online channels. By the year $2017,52 \%$ of the entire income from travel in Europe was generated through Internet channels, $45 \%$ in the USA, 37\% in Asia and $27 \%$ in Latin America (Charuta et al., 2016). In further topic analytics, it is emphasised that the fall in the shares of offline channels brings benefits to online tourist agencies and direct channels and that online tourist agency made up $23 \%$ of the entire travel market in 2017 , which is an increase of three percentage points in relation to the year 2015. Supplier-direct bookings grew $27 \%$ of the total market to $29 \%$ in the same period.

Despite the growing popularity of Internet channels, traditional agencies continue to remain the key component of European travel, and, during 2015, the share of bookings realised through travel agencies stood at $53 \%$. In future years, this share will be falling, and it is predicted that in 2020 the share of bookings realised through travel agencies will be $42 \%$. Since the share of bookings through classical tourist agencies is falling, the share of bookings realised through direct channels and through online tourist agencies is parallelly growing, analysed Golomohammadi (2012), with the rhetorical question: Booking online or not? As travellers are more and more often looking for the best prices, practicality and possibility of choice in large tourist agencies' Internet websites, bookings are more and more frequently made using smartphones, and thus classical booking methods are being slowly abandoned, as it is the case with tourist agencies and other "offline" reservation methods.

In 2015 , the share of direct channels equalled $57 \%$ of the total online tourism market in Europe, while, in 2017 , the share of direct channels fell by $1 \%$ and equalled $56 \%$. As, in recent years, the online tour operators (OTAs) record constant growth, direct channels are oriented towards the investment of substantial financial means into the improvement of their own online functionality and user experience with the aim to halt the increase in the OTA shares in the total online tourism market (Charuta et al., 2016). Reflecting on the implementation of innovations, Romero and Tejada (2020) stressed an interesting conclusion through which they illustrated the relationship and dependence of hoteliers on traditional tour operators and online travel agents. They pointed out that a higher level of dependence on tour operators leads to a lower level of adoption of innovations and openness towards online distribution channels, whereas a higher level of dependence on OTAs contributes to the use and immersion of technologies in the hotel business operations. Furthermore, O'Connor (2020) also tackled the problem area of the development of future hospitality business arising from the implementation of technological innovations; he analysed the indicators and presented possible feasible scenarios for future development of online distribution in hospitality and tourism, including further consolidation of the major players. He explored the "blurring of lines between organisation types and the substitution of existing systems by mainstream-commerce players".

In the online market, direct bookings continue to have an advantage over online tourist agencies. Their market share has grown in the last three years; in 2016, the share of direct bookings in the online market was $57 \%$ and, in $2018,59 \%$, analysed by Juman et al. (2016). They analysed how income from hotel accommodation sales has continuously grown from 2014 onwards. In 2017, income from hotel accommodation sales equalled 98 billion euros and, in 2018, it exceeded the figure of 100 billion euros, equalling 101 billion euros. The predictions before the emergence of the pandemic caused by the COVID-19 virus were that, by the year 2020 , gross hotel accommodation bookings would be 107 billion euros. The share of online bookings in total bookings is also continuously growing and, before the emergence of the 
COVID-19 virus, it was predicted that they would equal $42 \%$ in the year 2020 . As the first half of 2020 was affected by the COVID-19 virus, and it was expected that such a situation would last as long as until the end of the year, the current predictions are that gross hotel accommodation bookings in tourism in 2020 would equal a modest 58 billion euros, as claimed by Statista (2020). Such predictions are not unexpected, given the emergence of the coronavirus pandemic, which started at the beginning of 2020 , affecting all the world's countries and causing both health and economic problems, entailing long-term consequences, as discussed by Alonso et al. (2020). They pointed out that the aftermath of the COVID-19 pandemic would definitely impact innovations and changes in the hotel industry. They examined the impacts, coping strategies and adjustments in the light of COVID-19. Breier et al. (2020) further explored the issues of innovations in hotel business operations and models, and Jiang and Wen (2020) focused on reprogramming marketing and management in accordance with the "new normal".

Traditionally, tour operators were conducting their business in the offline market; their consumers were traditional, and therefore, there was no need to switch to the online market. During the last few years, and especially in Great Britain and the Scandinavian countries, where the changes in the behaviour of tourists, i.e. consumers, are most pronounced, tour operators have increasingly begun to turn to the online market. Some countries, such as Italy and Spain, continue to be traditionally offline markets, analysed by Charuta et al. (2016), adding that innovative online channels are growing in relation to realised bookings, but that gross bookings also continue to record constant growth.

Due to the complexity and relatively high prices related to holiday packages, the share of tour operators in the online market is relatively low, and, in 2017 , a mere $27 \%$ of bookings were made through Internet channels. A rapid ascending trend was also identified in 2019, as Menze (2019) pointed out. "Led by Europe's two largest markets - the UK and Germany - online bookings were projected to climb $6 \%$ in 2019, approximately three times the rate of overall market growth. For the first time, researchers found more than half of all European travel bookings were made online. Online growth of 4 to $5 \%$ is projected for the next several years, with most gains attributed to mobile platforms." Prior to the emergence of the COVID-19 virus, the estimate was that, by the year 2020, the share of online bookings would increase by a modest $2 \%$, equalling $29 \%$ of total bookings. However, significant differences can be noticed if different markets are observed, which corresponds to Menze's (2019) data. In consideration of the key impacts on the growth in bookings and their realisation (conversion rates), the significance of email marketing in the CRM system is recorded, which reach the existing and potential consumers predominantly through targeted newsletters (Floričić, 2018).

The increase in gross bookings in online tourist agencies was the largest in 2015 and 2016 and equalled $19 \%$ and $26 \%$, respectively. During all other years, the increase in gross bookings was even and equalled between six and nine per cent. When the booking growth is not observed in percentages but in billions of euros, gross bookings in 2015 equalled 52.7 billion euros and the predictions prior to the emergence of COVID-19 were that, by the year 2020, they would grow to nearly 74 billion euros (Juman et al., 2016).

One of the tourism market specificities is generally the spatial distance between supply and demand and the moment of linking supply and demand is of the utmost importance. An adequate organisation is needed of all hotel departments, as well as their continuous cooperation to achieve this. It no longer suffices to advertise and make promotions at tourism 
fairs, in brochures or on own websites; it is necessary to broaden horizons and to adapt to the market. With the swift rise in the number of online tourist agencies in the last few years, it is certainly important to use their influence in the market and, also through them, to sell accommodation capacities. We can, therefore, see numerous hotel chains offering their hotels through online tourist agencies, such as Booking.com, Hotels.com, Expedia and similar (Pilar et al., 2019). Hotels, however, lose a great deal of money on the commission they pay to tourist agencies and on governmental taxes and are now increasingly modernising their own websites in order to enhance the number of direct bookings. In this way, guests pay lower prices, reduced by online mediation commission fees and, in return, hotels offer a variety of facilities to their regular guests, thus benefiting all stakeholders. Biełuszko and Marciszewska (2018) explored the topic area of prices, tackling the issues of rate parity, price management and differentiation, as well as rate fences which hotels use in order to improve the competitiveness of their price in relation to other commissionable distribution channels.

In both versions, it is important to emphasise the significance of user experience (UX), which is one of the predominant factors in making decisions about bookings. User experience, as the core offering of a hotel, is conditioned by a series of services, from reception, staff, room décor, to the quality of the material components of hospitality services (Beldona \& Cobanoglu, 2007). Its initiation, however, begins with the booking process in the digital environment. User experience "implies and includes behaviours, attitudes and emotions which users experience during the use of a specific product, system or service", but it also takes into account the "usability, efficiency and ease of use" (Korkishko, 2019). Exploring the effects, it is stressed that an attractive web design, in combination with the entire website structure, must provide an interesting, personalised and responsive user experience based on functionality. Furthermore, he claims that $68 \%$ of users will leave the website because the design is not focused on users and that $97 \%$ of websites are disabled during the first couple of months due to poor UX (user experience) design, which is reflected in the short attention span and time which a user is prepared to spend in browsing. As for company websites, $48 \%$ of respondents state that they will think that the company is not trustworthy if the mobile website version does not function, and $44 \%$ of them will relate their bad online experience to their friends.

Korkishko (2019) classified the elements of user experience: (1) visual design, which includes graphic website elements; (2) information design, which pursues presentation of information on websites in the best possible way, from information structure through the order in which they are presented to implementation of website chatbots and live chats; (3) interaction design which "guides" users through websites - position, form and colour of particular elements (for example, buttons) direct users' movements on the website; (4) functional specifications; (5) user needs and (6) site objectives.

At their disposal, tourist offer holders have two possibilities for the placing of their product in the tourism market (Senečić \& Vukonić, 1997):

1. by means of direct distribution, when direct communication with guests is realised,

2. by means of indirect distribution, when mediators, who charge commission for their mediation services, are involved (travel agencies, tour operators, online tourist agencies, etc.) between accommodation capacity providers, in this case, hotels and the end-user, i.e. guests. 
Figure 1 | Distribution channels in hotels



Source: authors' contribution according to the data by Schegg, Roland. "European Hotel Distribution Study, Results for the Reference Year 2017" Institute of Tourism, HES-SO Valais, 2018, p. 17

When talking about direct distribution channels in hotels, we can divide them into bookings realised through telephone calls, emails or fax, through hotels' websites or by direct arrival at the hotel, while GDS, OTA and CRS tour operators are considered to be indirect channels. Flecha Barrio et al. (2016) exploreed them and presents and analyses the link between and dependence of hotel companies with stakeholders and distribution channel mediators. On the other hand, within the context of organisational and pricing distribution channel innovations, Berezina et al. (2016) identified flash sale offers as a momentary, dynamic and extremely efficient tool of short-term offers and placement. Innovative price diversification, commission policy and their impact on profitability are the topics presented by Ling et al. (2014) within the context of consideration of hotel business financial indicators ADR and RevPAR.

In Table 1, the trends of distribution channel market shares in Europe in the period between 2013 and 2017 of social networks and tourist boards are illustrated. 
Table 1 | Distribution channel market shares in Europe in the period between 2013 and 2017

\begin{tabular}{|c|c|c|c|c|c|c|}
\hline \multirow{2}{*}{$\begin{array}{l}\text { Total unreviewed sample (2,593 valid } \\
\text { samples) }\end{array}$} & \multicolumn{2}{|c|}{$\begin{array}{l}\text { Market share in } \\
2017\end{array}$} & \multicolumn{2}{|c|}{$\begin{array}{c}\text { Market share in } \\
2015\end{array}$} & \multicolumn{2}{|c|}{$\begin{array}{l}\text { Market share } \\
\text { in } 2013\end{array}$} \\
\hline & 18.5 & & 18.7 & & 21.1 & \\
\hline Directly: email or fax & 2.0 & & 2.3 & & 3.1 & \\
\hline $\begin{array}{l}\text { Directly: arrival at hotel (without } \\
\text { previous booking) }\end{array}$ & 4.4 & & 4.8 & & 6.0 & \\
\hline $\begin{array}{l}\text { Directly: completion of contact form } \\
\text { on website (without checking } \\
\text { availability) }\end{array}$ & 6.0 & 55.1 & 6.1 & 55.2 & 6.1 & 59.4 \\
\hline Directly: email & 16.0 & & 16.7 & & 16.1 & \\
\hline $\begin{array}{l}\text { Directly: real time booking through } \\
\text { website (with checking availability) }\end{array}$ & 8.2 & & 6.8 & & 6.9 & \\
\hline $\begin{array}{l}\text { Destination Management } \\
\text { Organisation (DMO) }\end{array}$ & 0.9 & 1.3 & 0.9 & 1.4 & 1.0 & 1.7 \\
\hline National Tourism Organisation & 0.5 & & 0.6 & & 0.6 & \\
\hline Tour operators / Tourist agencies & 7.8 & & 8.0 & & 9.6 & \\
\hline $\begin{array}{l}\text { Hotel chains and cooperation with } \\
\text { CRS }\end{array}$ & 1.0 & 12.7 & 2.6 & 16.3 & 1.4 & 15.7 \\
\hline $\begin{array}{l}\text { Wholesaler (Turico, Gulliver, } \\
\text { Transhotel..) }\end{array}$ & 1.9 & & 2.6 & & 2.8 & \\
\hline Event and congress organisers & 1.9 & & 3.1 & & 1.9 & \\
\hline Online Tourist Agencies (OTA) & 26.9 & 29.3 & 22.3 & 25.5 & 19.3 & 21.8 \\
\hline GDS & 1.9 & & 2.7 & & 2.0 & \\
\hline Social networks & 0.5 & & 0.5 & & 0.5 & \\
\hline Other distribution channels & 1.6 & 1.6 & 1.5 & 1.5 & 1.5 & 1.5 \\
\hline
\end{tabular}

Source: authors' contribution according to the data by Schegg, Roland. "European Hotel Distribution Study, Results for the Reference Year 2017" Institute of Tourism, HES-SO Valais, 2018, p. 18

The illustration of distribution channel shares in Croatia in 2017 follows below. 
Table 2 | Distribution channel market shares in Croatia in 2017

Total unreviewed sample $(n=32)$

Market share in 2017

\begin{tabular}{lll}
\hline Directly: telephone & 21.1 & \\
Directly: email or fax & 6.7 & 51.3 \\
Directly: arrival at hotel (without previous booking) & 3.3 & \\
$\begin{array}{l}\text { Directly: completion of contact form on website (without } \\
\text { checking availability) }\end{array}$ & 2.4 & \\
Directly: email & 13.4 \\
Directly: real time booking through website (with checking & 4.4 \\
availability) & & \\
\hline Destination Management Organisation (DMO) & 0.3 \\
National Tourism Organisation & 0.6 \\
\hline Tour operators / Tourist agencies & 21.7 \\
Hotel chains and cooperation with CRS & 0.5 \\
Wholesaler (Turico, Gulliver, Transhotel..) & 1.2 \\
\hline Event and congress organisers & 2.0 \\
\hline Online tourist agencies (OTA) & 19.5 \\
GDS & 1.2 \\
\hline Social networks & 0.2 \\
\hline Other distribution channels & 1.7 \\
\hline
\end{tabular}

Source: authors' contribution according to the data by Schegg, Roland. "European Hotel Distribution Study, Results for the Reference Year 2017" Institute of Tourism, HES-SO Valais, 2018, p. 59

The largest share in the total Republic of Croatia's market have direct booking channels and, through them, over $50 \%$ of bookings were realised.

\section{Methodology and research design}

The constant development of online distribution channels is one of the key elements of success. Post-COVID-19 tourism changes the rules, both concerning hotel operations as well as the distribution mix, where consumers tend to make short-term reservations and pursue flexible cancellation policies. The research was conducted between April and June 2018 and reflected the future trends of pre-COVID-19 distribution. These trends, affected by "new normal" standards of quality and safety, present implications for post-COVID-19 tourism development. Using the survey method, the data was collected concerning online hotel accommodation bookings in four and five-star hotels in the Republic of Croatia. The obtained respondents' answers will be compared with the existing reports on the online tourism market in Europe, such as Phocuswright's report on the online tourism market, $11^{\text {th }}$ edition, methodology Charuta et al. (2016) and $12^{\text {th }}$ edition (Juman et al., 2016), as well as the Hotrec study (Schegg, 2018) on distribution in the hospitality industry in Europe. The data collected from the survey will also 
help in drawing conclusions related to the trends in the booking of hotel accommodation in general, with an emphasis on online bookings.

Apart from the basic data collection methods and the technique of creative thinking, in the processing of this paper's topic, as well as in the research itself, the following appropriate scientific and research methods will also be used; primarily, the methods of analysis and synthesis, classification and comparison.

Using the research method and referring to Hotrec and Phocuswight's reports, the latest trends were explored in hotel accommodation bookings in Europe. By studying the said reports, a substantial amount of information was obtained about the modes of accommodation capacity bookings in hotels, the choice of channels through which reservations are made, which countries in Europe lead the use of online channels for accommodation bookings and which continue to be based on traditional booking channels and much more additional information. In addition, using the method of comparison, the information from the reports will be compared with the conducted survey questionnaire in order to compare the prevailing trends in the Republic of Croatia with those recorded in Europe, while the method of analysis and synthesis will be used to break down and link the characteristics and facts associated with the trends in online hotel accommodation bookings.

The survey questionnaire was devised in Google Forms application, where the questions were created and which were later distributed to email addresses of all hotel companies managing four and five-star hotels in the Republic of Croatia. In line with the principles of validity and reliability, the initial testing which was carried out in the Marketing and sales department of the hotel chain company Maistra Inc. and a modified version of the survey questionnaire was created (five suggestions regarding five questions were applied while one was not taken in consideration as not relevant to the focus of research). Then the modified version of the questionnaire was reviewed by another expert of marketing and sales from AHG Inc, a hotel chain company and by an Accademia colleague, respectively (testing of the validity), whereas one question was deemed as superfluous and was thus eliminated. The survey was distributed to a total of 147 hotel companies precisely on email addresses of the (marketing and/or) sales department decision-makers and responsible persons, encompassing 205 four and five-star hotels in the Republic of Croatia. The survey research was conducted in the period between April and June 2018, and a total of 61 responses were received; and the survey questionnaire results are shown below in the paper.

Since many hotels are part of a hotel chain, the respondents were asked to fulfil the survey having in mind their hotels of 4 and 5 *, as it was stated in the email announcing the survey. Out of 62 answers collected in total, one was unusable - with errors. Thus, the response rate is $61 / 147$, i.e. $41,50 \%$. Since the questionnaire was anonymous and the collected data were processed only in total, there is no way of knowing if there were respondents who submitted more than one answer per hotel company, as the questionnaire was sent out for compilation three times in total (two reminders followed the first email), representing thus a limitation of the research.

The questionnaire consisted of ten questions and represented an original framework of research developed in this paper. Nine questions were close-ended (five with one answer possible, one with more answers possible and three questions investigated importance 
and/range of selected elements), and just one question was semi-open ended. The research can be easily replicated by another researcher and institution, which contributes to its reliability.

\section{Results and discussion}

The respondents are, in the largest percentage, hotels that have between 100 and 299 accommodation capacities, followed by hotels with a total of between 29 to 99 accommodation capacities and the lowest number of responses were provided by hotels that have the lowest number of accommodation facilities (up to 25 accommodation units).

The survey questionnaire respondents were mainly employees of hotels that do not belong to any international chains, and therefore the answers largely represent the responses of independent four and five-star hotels in the Republic of Croatia.

In the following question, the respondents were offered a total of seven channels of indirect distribution of hotel accommodation, which they were asked to rank according to the importance which each one of them represents for their hotels (importance 1, importance 2, importance 3, importance 4, importance 5, importance 6, importance 7).

The average value of the importance of the offered answers is 4, which would mean that, for the respondents, on average, indirect distribution channels equal importance 4.

To the question on the estimate of the percentage of bookings realised by means of direct sales channels (own websites and booking centres) in 2017, the majority of respondents answered that such bookings make a share of between 30 and $39 \%$ of total bookings $(59 \%$ of respondents), and the lowest number of respondents answered that direct bookings make between 60 and $69 \%$ of total bookings (1.6\% of respondents). On average, the respondents realised $30.83 \%$ of bookings through direct sales channels (own websites and booking centres) in 2017.

In the largest measure, the respondents notice an increase in direct bookings, realised through own websites and booking centres. If we compare the data from the question about what percentage from the total number of bookings are made up of direct bookings (30-39\%) and that the respondents in the largest measure notice an increase in the number of direct bookings in relation to the previous year $(78.7 \%$ of them), we can arrive at the conclusion that direct bookings are growing and that they will continue to have a growth tendency.

The estimate of the majority of respondents was that, through their own online booking system (own website), they realised between 20 and $29 \%$ of bookings in 2017 (31.1\% of respondents). On average, the respondents realised $20.86 \%$ of bookings through their own online booking system (own websites) in 2017.

In the next question, using the scale between 1 and 5 ( 1 =not at all important for me, $5=$ very important for me), the respondents were asked to rank each of the below-stated elements which affect improvement/increase in sales. 
Table 3 | Rank table of importance of indirect distribution channels

\begin{tabular}{lcc} 
Indirect distribution channels & $\begin{array}{c}\text { Average value of } \\
\text { importance } \\
\text { (arithmetic mean } \\
\text { AS) }\end{array}$ & Median (Me) / St Dev \\
\hline Online tourist agencies & 5.41 & $6 / 2.23$ \\
Tour operators and tourist & 5.33 & $6 / 2.11$ \\
Agencies & & \\
Social networks & 4.30 & $4 / 1.37$ \\
Congress and event organisation & 3.87 & $1 / 1.20$ \\
Tourist boards & 3.48 & $4 / 1.55$ \\
Other indirect distribution channels & 3.43 & $4 / 1.78$ \\
GDS & 2.20 & $3 / 1.67$ \\
\hline AS $=4$ & & \\
Me $=4$ & & \\
\hline
\end{tabular}

Source: authors' contribution

Table 4 | Rank table of elements affecting increase in sales through own website

\begin{tabular}{|c|c|c|}
\hline Element & $\begin{array}{c}\text { Average value of } \\
\text { importance (arithmetic } \\
\text { mean= AS) }\end{array}$ & $\begin{array}{l}\text { Median (Me) } \\
\text { / St Dev }\end{array}$ \\
\hline Recent reviews & 4.61 & $5 / 0.61$ \\
\hline Simple navigation & 4.56 & $5 / 0.89$ \\
\hline Good offers and promotions & 4.56 & $5 / 0.62$ \\
\hline Server security & 4.48 & $5 / 0.96$ \\
\hline Best price guarantee & 4.41 & $5 / 0.69$ \\
\hline Brand power & 4.41 & $5 / 0.67$ \\
\hline Optimisation for mobile appliances & 4.33 & $5 / 0.81$ \\
\hline Use of suitable content & 4.31 & $4 / 0.74$ \\
\hline Use of right media for promotion & 4.31 & $5 / 0.87$ \\
\hline Dynamic pricing & 4.26 & $4 / 0.82$ \\
\hline $\begin{array}{l}\text { Creation of mobile applications for accommodation } \\
\text { booking }\end{array}$ & 4.20 & $5 / 1.05$ \\
\hline Different interactive contents & 4.15 & $4 / 0.83$ \\
\hline User experience on website & 4.15 & 4 / 0.91 \\
\hline Accessibility & 4.03 & $4 / 0.82$ \\
\hline Technical performances & 3.52 & $4 / 1.04$ \\
\hline Live chat with potential guests & 2.41 & $2 / 0.84$ \\
\hline $\begin{aligned} \mathrm{AS} & =4.16 \\
\mathrm{Me} & =4.0\end{aligned}$ & & \\
\hline
\end{tabular}


To the offered statements which needed to be ranked on the scale of between 1 and 5, where 1 represents the answer "not at all important for me" and 5 represents the answer "very important for me", the largest number of respondents gave the answer 5 = "very important for me". The respondents consider website simple navigation, server security, recent reviews, good offers and promotions as the most important, while the least important for them seem to be the possibility of live chat with potential guests, slow website loading, which is conditioned by technical performances, as well as the availability of several languages on the website. The average importance has chosen by the respondents as answers equalled the importance 4.16, while the median value equals 5 . Although not at the top of the list of categories which, in their opinion, could improve hotel business operations, the respondents believe that the development of mobile applications for accommodation bookings and optimisation of websites for mobile appliances can considerably contribute to the enhancement of business operations, especially taking into account the fact that modern tourists increasingly use technology.

Further data analysis revealed a disproportion in the importance of elements that affect the increase in sales through own websites. Namely, in table 4, the data indicates that live chat with potential guests, an element that can have a significant impact on user experience, is actually not present (avg. value 2.41). On the other hand, the theory points out the fact that, although online is predominantly taking over the leading positions in the hotel distribution channels, the importance of traditional channels, characterised by inter-personality, personal user experience and communication, continue to show an ascending trend. Considering the discussed problem area, interpretation of these positions can be found in the beginnings of the introduction of the chatbot technology and in overcoming consumer scepticism towards using it. Namely, according to the table 5 data, consumers grade user experience mostly as an element that would contribute to the intensification of their interests and realisation of bookings.

The respondents also stated some other elements which could help to improve business operations but which had not been mentioned earlier. The majority of respondents believe that better destination promotion, peace in the world, political safety in the region and other tourism destinations (Greece, Turkey), employment of adequate workforce, employee education and higher quality offers in the destination during pre-and post-season periods would also help. Some of the other respondents' suggestions relate to an increase in the number of flights at nearby airports, better hotel advertising, better quality of promotional photographs and videos, as well as improvement of marketing activities.

The respondents were offered elements that could affect the increase in accommodation capacity sales, and they were asked to list them in order of the importance that each element represents for them. 
Table 5 | Rank table of elements which would increase accommodation capacity sales

\begin{tabular}{lcc}
\hline \multicolumn{1}{c}{ Element } & $\begin{array}{c}\text { Average value of } \\
\text { importance }(\text { arithmetic mean }= \\
\text { AS) }\end{array}$ & $\begin{array}{c}\text { Median } \\
(\text { Me) } / \text { St } \\
\text { Dev }\end{array}$ \\
\hline User experience & 2.56 & $2 / 1,16$ \\
Products and services & 2.51 & $3 / 1,15$ \\
Technology & 2.48 & $3 / 0,91$ \\
Company management & 2.46 & $2 / 1,26$ \\
\hline AS = 2.5 & & \\
Me = 2.5 & &
\end{tabular}

Source: authors' contribution

For the respondents, each of the offered elements, on average, has the importance equalling 2.5 , while the median value stands at 2.5. Standard deviation enables the assessment of variances of answers. Looking collectively at the individual data, we can conclude that it revolves around the same average, which would mean that all the offered elements were equally important for the respondents.

In the hotel business, there are also various obstacles that affect hotel processes, accommodation occupancy rate and impact business operations in general. According to the research, some of the most important are the following: workforce problems and this also in the sense of inadequate qualification, competencies and skills, as well as their multitude. An important obstacle affecting and hindering business operations is the legal and political environment, and the respondents also quote a lack of financial resources as an element that affects the hotel business operations in general. Ranking of the above-mentioned obstacles at the very top is a result of a non-supportive entrepreneurial macro environment. When considering the positions of the 2020 tourism and hospitality industry impacted by the COVID19 global pandemic, the future of Post Covid tourism and competitiveness are very uncertain. The new technologies enable new models of consumers' behaviour, new habits emerge, and, therefore, the marketing strategies of hotel companies should follow that new path of Post Covid consumers demand.

\section{Conclusion}

After the conducted survey and the analysis of the data obtained, it is possible to deduce several conclusions. In the Republic of Croatia, hotels, especially the independent ones, which do not belong to any hotel chains, consider the global distribution system (GDS) as being the most important channel among the indirect booking channels, which is a rather traditional attitude. Although most of the respondents $(51 \%$ of them) stated that, for them, global distribution systems did not represent great importance in indirect distribution channels, according to the data from the European Hotel Distribution Study, in the Republic of Croatia in 2017 , only $1 \%$ of bookings were realised through the global distribution systems. For the majority of hotels, especially those with a smaller number of accommodation capacities, family hotels and others that have not been mentioned here, which employ smaller workforces and have limited financial means, linking to global distribution systems is too expensive an investment, and they use Channel Managers in order to place their hotels and accommodation capacities in the market. Also, many respondents consider social networks as extremely 
important indirect booking channels. Such an approach points to the following trends and turning towards younger populations of tourists, who are the biggest social network users.

Concerning booking channels which include own website systems and own booking centres, the respondents mostly replied that they felt an increase in direct bookings as opposed to the previous year and the largest number of the respondents estimated that they realised between 30 and $40 \%$ of bookings through direct channels, of which they realise between 20 and $29 \%$ of bookings through their own online booking systems. Own online booking systems record bookings in approximately the same range as in the European average where, in 2017, approximately $38 \%$ were online hotel bookings. Comparing the data at the European level and the data at the level of the Republic of Croatia obtained from the survey of respondents, it is possible to arrive at the conclusion that the Republic of Croatia fits into the European average. The respondents perceive an increase in direct bookings, realised through own websites and booking centres in 2017 in relation to the previous year, 2016 (79\% of respondents). Also, an increase in the shares of bookings realised through direct channels is noted in relation to the bookings realised through online tourist agencies, due to constant investment in technology and monitoring of trends in the tourism markets, and all for the purposes of increasing competitiveness. In the Republic of Croatia, respondents greatly invest in relatively new distribution channels, such as social networks and, in this way, plan to attract a larger number of the younger generation tourist population. Apart from online tourist agencies, as a dominant platform for indirect bookings, the global booking systems, as traditional indirect booking channels, remain in the shadow, although, in some countries, the global distribution systems continue to receive somewhat higher importance. However, in any case, this concerns negligible numbers. The largest contribution of this paper is reflected in the detection of trends in hotel accommodation in the Republic of Croatia, perception of the shortcomings that the respondents quote, and it is that very data that generates important implications, both for the theory and the practice, thus imposing the need for improvement of the current situation in which both theoreticians and practitioners would synergically act. The limitation of the conducted research is manifested by the personal participation of the authors' in the implementation of the survey and in the data analysis, as well as the chosen sample, four and five-star hotels in the Republic of Croatia. This, however, does not point to the general picture of the Croatian hospitality industry but implies the trends of the stated categories. Also, this research has a spatial limitation, given that it was conducted only on hotels and hotel chains in the Republic of Croatia. It is, therefore, impossible to compare the obtained results with other countries, both in the European Union or the world, and it represents a foundation for further consideration and analysis of this problem area.

Although this survey research has the aforementioned limitations, it is those very limitations that can represent a starting point and guidelines for future research. The recommendation for future research is to conduct a survey questionnaire on a representative sample which will also encircle two and three-star hotels in the Republic of Croatia in order to obtain fuller research results. Also, as the research is replicable and could be conducted in other hotel companies in other European tourism countries, it could present a platform for comparative studies and new knowledge acquiring. Continuously, identical research is recommended, conducted in some other country which, by its characteristics, is similar to the Republic of Croatia (number of inhabitants, number of hotel accommodation capacities, etc.), as well as making a comparison of the obtained research results. 
Post-COVID-19 tourism changes the rules, both for hotel operations as well as the distribution mix, where consumers tend to make short-term reservations and pursue flexible cancellation policies. Future research should also investigate how innovative distribution strategies change the market visibility and sales through ADR and RevPAR and what the challenges of their application are.

This would contribute to the comprehension of new knowledge and its application in transformative and developmental processes aimed at new competitiveness.

\section{Acknowledgement}

This paper is a result of the scientific project "Tourism Development and Impact on Destination" supported by the Faculty of Economics and Tourism "Dr Mijo Mirković", Juraj Dobrila University of Pula. Any opinions, findings, and conclusions or recommendations expressed in this paper are those of the author(s) and do not necessarily reflect the views of the Faculty of Economics and Tourism "Dr Mijo Mirković" Pula.

The publishing of this paper is financially supported by Juraj Dobrila University of Pula, Project Tourism Development and Impact on Destination and by the authors personally.

The authors declare no conflict of interest.

\section{References}

Alonso, A. D., Kok, S. K., Bressan, A., O'Shea, M., Sakellarios, N., Koresis, A., ... \& Santoni, L. J. (2020). COVID-19, aftermath, impacts, and hospitality firms: An international perspective. International Journal of Hospitality Management, 91, 102654, https://doi.org/10.1016/j.ijhm.2020.102654

Beldona, S., \& Cobanoglu, C. (2007). Importance-performance analysis of guest technologies in the lodging industry. Cornell Hotel and Restaurant Administration Quarterly, 48(3), 299-312, https://doi.org/10.1177/0010880407304023

Berezina, K., Semrad, K. J., Stepchenkova, S., \& Cobanoglu, C. (2016). The managerial flash sales dash: Is there advantage or disadvantage at the finish line?. International Journal of Hospitality Management, 54, 12-24, https://doi.org/10.1016/j.ijhm.2016.01.003

Biełuszko, K., \& Marciszewska, B. (2018). Room rate parity vs. rate fences in the context of price discrimination theory: The case of the Polish hospitality market. Argumenta Oeconomica, 41(2), https://doi.org/10.15611/aoe.2018.2.05

Bramwell, B. (2020). Brexit and Tourism. Process, Impacts and Non-policy, Current Issues in Tourism. Elsevier Ltd., UK, published online ahead of print, https://doi.org/10.1080/13683500.2020.1761606.

Breier, M., \& Kallmuenzer, A. \& Clauß, T. \& Gast, J. \& Kraus, S., \& Tiberius, V. (2020). The role of business model innovation in the hospitality industry during the COVID-19 crisis. International Journal of Hospitality Management. https://doi.org/10.1016/j.ijhm.2020.102723.

Dutta, A., Mishra, T., Uddin, G. S., \& Yang, Y. (2020). Brexit uncertainty and volatility persistence in tourism demand. Current Issues in Tourism, 1-8, https://doi.org/10.1080/13683500.2020.1822300

Flecha Barrio, M. D., Talón Ballestero, M. P., Figueroa Domecq, C., \& Abad Romero, P. (2016). The role of OTAs in the distribution process of Spanish Hotel Chains. ESIC Market. Economic \& Business Journal, 47(3). 
Floričić, T. (2018). Digital tourism promotion and E-mail marketing. In Dvouletý O., Lukeš, M., Misar, J. (eds.) Proceedings of the 6th international conference: IMES 2018. Prague, Vysoká škola ekonomická v Praze, Nakladatelství Oeconomica - Praha, Czech Republic.

Charuta, F., Merten, R., \& Finkowski, F. (2016). European Online Travel Overview. PhocusWhight.

Golomohammadi, A. (2012). Booking online or not: a decision rule approach, Tourism management perspectives, 1 (9), https://doi.org/10.1016/j.tmp.2012.03.004

Jiang, Y., \& Wen, J. (2020). Effects of COVID-19 on hotel marketing and management: A perspective article. International Journal of Contemporary Hospitality Management, 32(8), https://doi.org/10.1108/lJCHM-03-2020-0237.

Juman, D., Eisenbeis, F., \& Merten, R. (2016). European Online Travel Overview. PhocusWhight.

Kot, H. W., Chen, M. H., \& Huang, H. (2019). Understanding short selling activity in the hospitality industry. International Journal of Hospitality Management, 82, 136-148, https://doi.org/10.1016/j.ijhm.2019.03.029

Korkishko, I. (2019). Key parts of UX design. Accessed on 10.08.2020, retrieved from https://medium.com/swlh/key-parts-of-ux-design-2bd479b9348c

Ling, L., Guo, X., \& Yang, C. (2014). Opening the online marketplace: An examination of hotel pricing and travel agency on-line distribution of rooms. Tourism management, 45, 234-243, https://doi.org/10.1016/j.tourman.2014.05.003

Mawby, R. I., Ozascilar, M., \& Ziyalar, N. (2021). Risk, safety and security among visitors to Istanbul. Tourism and Hospitality Research, 21(1), 61-72, https://doi.org/ $10.1177 / 1467358420948918$

Menze, J. (2019). The research spotlight, the state of the European online market. https://www.phocuswire.com/research-spotlight-european-online-travel-overview-2019.

O‘Connor, P. (2020). Online tourism and hospitality distribution: A perspective article. Tourism Review, 75(1), https://doi.org/10.1108/TR-06-2019-0216

Pilar, L., Slivar, I., \& Floričić, T. (2019). Preferred E-promotion strategies of international hotel chains Insight and evaluation. In: Lukeš, M., Misar, J. (eds.). Proceedings of 7th international conference, IMES 2019. Prague, Vysoká škola ekonomická v Praze, Nakladatelství Oeconomica - Praha, Czech Republic.

Romero, I., \& Tejada, P. (2020). Tourism intermediators and innovation in the hotel industry. Current Issues in Tourism, 23(1), https://doi.org/10.1080/13683500.2019.1572717

Senečić, J. I., \& Vukonić, B. (1997). Marketing u turizmu. Mikrorad d.o.o.

Schegg, R. (2018). European Hotel Distribution Study, Results for the Reference Year 2017. Institute of Tourism, HES-SO Valais.

Sigala, M. (2020). Tourism and COVID-19: Impacts and implications for advancing and resetting industry

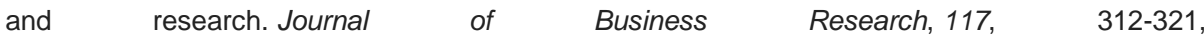
https://doi.org/10.1016/j.jbusres.2020.06.015

Statista. (2020). Revenue in the travel \& tourism market in Europe from 2017-2023, Hamburg, Germany. https://www.statista.com/forecasts/891263/revenue-in-the-travel-and-tourism-market-in-europe.

Tauringana, V., Tingbani, I., Okafor, G., \& Sha'ven, W. B. (2020). Terrorism and global business performance. International Journal of Finance \& Economics, https://doi.org/10.1002/ijfe.2085 
Vrana, V., Zafiropoulus, K., Antoniadis, K., \& Theocharidis, A. I. (2017). Measuring the Twitter performance of hotel E-Mediaries, Tourism, Culture and Heritage in Smart Economy. Springer.

Vrkljan, S., \& Bognar, Z.B. (2017). The model of key competitive factors of global chain hotels. Proceedings of 4th international scientific conference TOSEE 2017, Opatija, Croatia.

The research article passed the review process. | Received: December 14, 2020; Revised: March 5, 2020; Accepted: March 5, 2020; Pre-published online: June 30, 2021; Published in the regular issue: March 16, 2022. 